\title{
IMPLIKATUR DALAM NOVEL SEPATU DAHLAN KARYA KHRISNA PABICHARA
}

\author{
Muhammad Harsan, Yarno, Panji \\ Program Studi Pendidikan Bahasa dan Sastra Indonesia, FKIP UMSurabaya \\ muh.harsan.pbsi@gmail.com
}

\begin{abstract}
ABSTRAK
Tujuan dari penelitian ini adalah 1) Mendeskripsikan implikatur percakapan dalam novel Sepatu Dahlan karya Khrisna Pabichara,2) Mengetahui implikatur percakapan dalam novel Sepatu Dahlan karya Khrisna Pabichara. Metode penelitian yang digunakan dalam penelitian ini adalah metode analisis data dengan metode kualitatif. Penelitian ini dilakukan dengan cara mendata percakapan yang mengandung implikatur percakapan dalam novel Sepatu Dahlan karya Khrisna Pabichara, setelah itu menganalisis. Hasil penelitian ini dapat disimpulakan, implikatur percakapan dalam novel Sepatu Dahlan karya Khrisna Pabichara menggunakan implikatur konversional. 23 sampel percakapan yang memiliki implikatur perckapan dalam novel Sepatu Dahlan karya Khrisna Pabichara, daam percakapan memiliki makna, novel Sepatu Dahlan karya Khrisna Pabicahara setiap percakapan mentaati ciri-ciri implikatur percakapan. Implikasi dari novel Sepatu Dahlan diharapkan menjandi salah satu pertimbangan pembelajaran, sebagai saran komunikasi dalam mengolah, menalar, dan menyajikan informasi lisan dan tulisan melalui teks cerita sejarah, berita, iklan, editorial/opini, dan novel.
\end{abstract}

Kata Kunci: Implikatur percakapan, Novel Sepatu Dahlan.

\begin{abstract}
The objectives of this research are 1) Describe the conversational implicature in the novel Dahlan by Khrisna Pabichara, 2) Know the conversational implicature in the novel Dahlan Shoes by Khrisna Pabichara. The research method used in this study is a method of data analysis with qualitative methods. This research was conducted by recording conversations that contained conversational implicatures in the novel Dahlan's Shoes by Krishna Pabichara, after which it was analyzed. The results of this study can be concluded, the conversational implicature in the novel Sepatu Dahlan by Khrisna Pabichara uses conversion implicature. 23 conversation samples that have a perceptual implicature in the novel Dahlan by Khrisna Pabichara, in conversations have meaning, the novel Dahlan's work by Khrisna Pabicahara every conversation obeys the characteristics of conversational implicature. The implications of the novel Sepatu Dahlan are expected to encompass one of the considerations of learning, as a communication suggestion in processing, reasoning, and presenting verbal and written information through historical stories, news, advertisements, editorials, and novels.
\end{abstract}

Keywords: Conversational Implications, Sepatu Dahlan Novel. 


\section{PENDAHULUAN}

Bahasa sebagai lambang bunyi yang arbitrer dipergunakan oleh masyarakat untuk berhubungan dan kerja sama, berinteraksi, dan mengidentifikasikan diri. Bahasa sebagai alat komunikasi mempunyai peranan yang penting dalam interaksi manusia. Bahasa dapat digunakan manusia untuk menyampaikan ide, gagasan, keinginan, perasaan, dan pengalamannya kepada orang lain. Tanpa bahasa manusia akan lumpuh dalam komunikasi maupun interaksi antar individu maupun kelompok.

Bahasa merupakan jembatan dalam berkomunikasi yang sangat dibutuhkan oleh setiap individu. Komunikasi yang dilakukan dalam kehidupan sehari-hari tidak selalu diwujudkan dalm bentuk lisan, tetapi juga diterapkan dalam tulisan. Setiap melakukan tidakan komunikasi, penutur mengharapkan pendengar atau penutur mengerti dan mampu apa yang ingin diinformasikan sehingga tidak terjadi kesalah pahaman. Agar tidak terjadi salapaham, seseorang harus mengetahui dan memahami pemakaian kata yang dalam berkomunikasi yang sesuai dengan situasi dan kapan berbicara. Salah satu yang harus dilakukan adalah diskusi atau pilihan kata.

Setiap individu memiliki caranya tersendiri dalam menyampaikan informasi. Dalam situasi atau konteks tertentu, penutur atau orang yang menyampaikan tuturan memberikan informasi yang lebih dari apa yang dikatakannya. Maksud atau informasi yang disampaikan lebih banyak secara tidak langsung kepada petutur. Untuk menangkap informasi tersebut penutur harus mengerti konteks pembicaraan dan bekerja keras dalam memahami tanda-tanda yang diberikan oleh penutur, informasi yang berlebih dari yang dimaksud dalam hal ini melanggar prinsip kerja sama percakapan. Pelanggaran terhadap prinsip kerja sama percakapan terkadang sangat diperlukan dalam konteks tertentu. Hal tersbut bisa disebut sebagai implikatur percakapan dalam komunikasi.

\section{METODE PENELITIAN}

Penelitian ini menggunakan metode analisis data dengan metode kualitatif. Moleong (2013:6) menjelaskan bahwa penelitian kualitatif adalah penelitian yang bermaksud untuk memahami fenomena tentang apa yang dialami oleh subjek penelitian misalnya perilaku, persepsi, motivasi, tindakan, dll., secara holistik, dan 
dengan cara deskripsi dalam bentuk kata-kata dan bahasa, pada suatu konteks khusus yang alamiah dan dengan memanfaatkan berbagai metode alamiah.

Dari definisi di atas dapat diperoleh simpulan penelitian kualitatif adalah penelitian yang dimaksud untuk memahami fenomena tentang apa yang dialami oleh subjek misalnya prilaku, perepsi, motivasi, tindakan, dan lain-lain.

Dalam Penelitian ini implikatur percakapan dalam novel Sepatu Dahlan akan dianalisis berdasarkan fakta-fakta yang ditemukan. Penelitian menggunakan deskripsi analisis, karena hasil dari penelitian ini berupa penalaran dan tidak menggunakan angka-angka seperti penelitian kantitatif.

\section{PEMBAHASAN}

Data yang didapat dalam novel Sapatu Dahlan karya Khrisna Pabichara di analisis percakapan yang mengandung implikatur-implikatur, percakapan tokoh dalam novel Sepatu Dahlan.

\section{Data 1}

Bapak : Dan, bagaimana bisa ada dua angka merah di dalam ijazahmu? Dahlan : Апиииu, pak, апиии.... (SD, Khrisna, 2012: 19)

Pada data yang pertama ini terdapat suatu implikatur percakapan. Dalam pecakapan tersebut Bapak memarahi Dahlan karena mendapatkan nilai angka merah hasil ujiannya, sedangkan Dahlan menjawab dengan berpatah-patah "апиии pak, апиии...” Dahlan tidak bisa mejawab apa yang seharusnya.

Berdasarkan percakapan di atas Dahlan tidak bisa memberi asalan yang tepat untuk menjawab pertanyaan Bapaknya, dikarenakan memang Dahlan mendapatkan nilai angka merah. Jadi ucapan Dahlan memiliki implikatur.

Berdasarkan analisis tersebut maka untuk menunjang analisis, penelitian memperkuatnya dengan memaparkan ciri-ciri implikatur berikut.

1. Dapat dibatalkan, maksudnya pernyataan yang diberikan oleh penutur dapat dibatalkan, dari percakapan di atas capan Dahlan mengandung implikatur, bahwa Dahlan tidak bisa memberi alasan apa yang di ucapan Bapaknya. Ucapan Dahlan “апииu pak, апииu..." ucapan ini Dahlan membatalkan ucapan Bapaknya. 
2. Makna ungkapan, dalam kata “апииu...” kata ini mengandung makna, ucapan tersebut makna yang tersimpan dari tutur bukan bagian ungkapannya.

3. Tak terbatas, ucapan Dahlan tak terbatas karena tidak terikat secara harfiah atau tidak berdasarkan ucapan penutur.

\title{
Data 2 \\ Dahlan : Tumben bikin sambel, $\mathrm{Bu}$. \\ Ibu : Tadi Ibu terima upah mbatik \\ (SD, Khrisna, 2012: 44)
}

Pada percakapan ini ucapan Dahlan mengenai sambel yang dibikin sama Ibunya dan Ibunya menjawab tadi Ibu terima upah mbatik, implikatur percakapan di atas Dahlan heran karena baru kali ini Ibunya bikin sambel, maksud dari jawaban Ibu tersebut ia mendapatkan upah dari hasil mbatik dan hasil upah yang diperoleh tersebut Ibu membeli cabe dan bikin sambel. Jadi ucapan Ibu adalah implikatur.

Berdasarkan analisis tersebut maka untuk menunjang analisis, penelitian memperkuatnya dengan memaparkan ciri-ciri implikatur berikut.

1. Makna ungkapan dari percakapan Ibu dan Dahlan, ucapan Dahlan “tumben bikin sambel, $\mathrm{Bu}$ ” makna ucapan tersebut adalah Dahlan merasa heren sama Ibunya karena baru pertama kali bikin sambal. Dari ucapan Ibu "tadi Ibu terimah upah mbatik” makna ucapan tersebut Ibu menerimah uang dari hasil membuat batik.

2. Tak terbatas, ucapan Ibu tersebut tak terbatas karena ucapan Ibu tidak terikat secara harfiah atau tidak berdasarkan penutur.

\author{
Data 3 \\ Dahlan : Bu, tadi Dahlan ndaftar tim voli. \\ Ibu : Bagus to. \\ Dahlan : Tapi...,nanti sepertinya butuh sepatu, Bu. \\ Ibu : Sabar, ya Le, insya Allah Ibu akan belikan sepatu. \\ (SD, Khrisna, 2012: 45)
}

Pada percakapan di atas Dahlan menceritakan pada Ibunya bahwa Dahlan daftar ikut main voli, Ibu hanya mejawab dengan senang hati kerena anak bisa daftar main voli. Di percakapn yang selajutnya Dahlan membutuhkan sepatu supaya nanti bisa ikut main voli, “tapi...,nanti sepertinya butuh sepatu”, ucapan Dahlan agak sungkan 
karena melihat ekonomi yang tidak memcukupi karena ibu tidak punya uang. Jadi implikatur yang terdapat pada percakapan di atas adalah uacapan Dahlan yang kedua.

Berdasarkan analisis tersebut maka untuk menunjang analisis, penelitian memperkuatnya dengan memaparkan ciri-ciri implikatur berikut.

1. Dapat dibatalkan, ucapan Dahlan yang kedua membatalkan dari ucapan Ibunya lihat dari ucapan tersebut "tapi..., nanti sepertinya butuh sepatu”, kata “tapi” ini yang dimanakan dibatalkan karena ucapan Dahlan berpatah-patah.

2. Makna ucapan, makna dari ucapan percakapan di atas "tapi..., nanti sepertinya butuh sepatu, Bu”, makna ucpan tersebut adalah pada saat main voli nanti Dahlan membutuhkan sepatu, "sabar, ya, Le, Insya Allah Ibu akan belikan sepatu” maknanya kalau Ibu punya uang nanti sepatunya akan dibelikan.

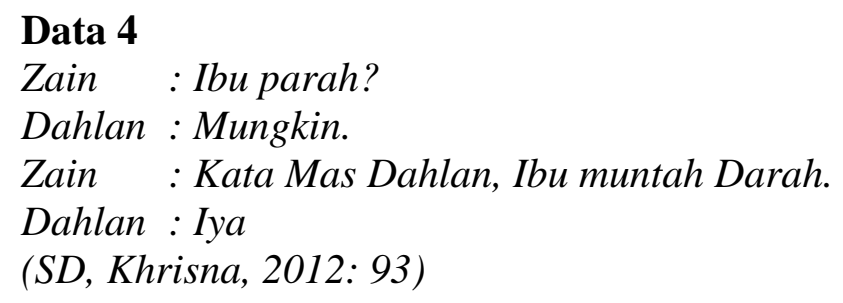

Percakapan di atas di mana Zain menanyakan pada Dahlan apakah Ibunya sakit parah. Implikatur dari percakapan tersebut “mungkins”, maksud dari kata mungkin Dahlan tidak beicara banyak takut Zain kenapa-kenapa karena Ibunya sakit parah, ucapan Dahlan yang pertama menutupi bahwa Ibunya sakit parah. Jadi implikatur yang timbul dari percakapan di atas ucapan Dahlan yang pertama.

Berdasarkan analisis tersebut maka untuk menunjang analisis, penelitian memperkuatnya dengan memaparkan ciri-ciri implikatur berikut.

1. Makna Ungkapan, dari ungkapan Dahlan 1 “mungkin” makna ucapan tersebut Dahlan 1 tidak tahu pasti dengan kondisi Ibunya dan bisa juga makna kata tersebut Dahlan 1 menutupi karena Ibunya benar-benar parah.

2. Dapat dibatalkan, ucapan Dahlan 1 membatalkan pertanyaan Zain 1 "mungkin” kata tersebut Dahlan membatalkan pertanyaan Zain 1, karena Dahlan takut adiknya Zain bersedih mendengar kondisi Ibunya. 


\section{Data 5}

Zain : Magrib Mas....

Dahlan : Makan dulu, baru salat.

(SD, Khrisan, 2012: 97)

Situasi percakapan di atas pada saat magrib, Zain menyuruh Dahlan untuk sholat karena Dahlan lapar ia makan dulu sebelum sholat. Jadi implikatur percakapan di atas Zain tidak menyebut sholat Zian hanya menyebut Magrib.

Berdasarkan analisis tersebut maka untuk menunjang analisis, penelitian memperkuatnya dengan memaparkan ciri-ciri implikatur berikut.

1. Makna ungkapan, makna dari ucapan Zain “Magrib Mas....”, arti ucapan tersebut bahwa magrib terlatiba maknanya Zain menyuruh Dahlan untuk sholat magrib dulu sebelum makan. Makna dari ucpan Dahlna “makan dulu, baru solat”, makna dari ucapan tersebut makan dulu biar pada saat sholat tidak terganggu karena lapar.

2. Dapat dibatalkan, dari ucapan Dahlan, Dahlan membatalkan ucapan Zain, karena Dahlan mau makan dulu maru sholat.

3. Tak terbatas, ucapan kedua percakapan tersebut saling tak terbatas, dalam ucapan Zain tidak menyebut kata "sholat" Zain hanya bilang "magrib”. Dan ucapan Dahlan tersebut tak terikat secara harfiah.

\section{Data 6}

Maryati : Malu?

Dahlan : Ndak enak.

(SD, Khrisna, 2012: 112)

Dari percakapan di atas Dahlan merasa sungkan dan malu dibonceng seorang wanita.

Berdasarkan analisis tersebut maka untuk menunjang analisis, penelitian memperkuatnya dengan memaparkan ciri-ciri implikatur berikut.

1. Dapat dibatalkan, ucapan Dahlan membatalkan dari ucapan Maryati, ucapan Dahlan tersebut menutupi karena Dahlan merasa sungkan kalau dibonceng sama Maryati.

2. Makna ungkapan, makna dari ucapan “ndak enak” artinya tidak enak dibonceng wanita, apa nanti kata orang-orang kalau dibonceng wanita. 


\section{Data 7}

Maryati : Eh, kok diam.

Dahlan : Iya, aku suka pisang.

(SD, Khrisan, 2012: 114)

Terjadi peracakapan di atas disaat Dahlan melihat pisang yang ada di rumahnya Maryati. Yang tibul dari percakapan di atas Maryati tidak menanyakan kepada Dahlan suka atau tidak dengan pisang, Dahlan menjawab ia suka sama pisang yang bernarnya bukan itu yang ditanyakan sama Maryati. Implikatur dari percakapan di atas adalah Dahlan.

Berdasarkan analisis tersebut maka untuk menunjang analisis, penelitian memperkuatnya dengan memaparkan ciri-ciri implikatur berikut.

1. Tak terbatas, dari ucapan Dahlan tidak terikat secara harfiah.

2. Makna dari ucpan Dahlan tersebut bahwa Dahlan sangat suka makan pisang

\section{Data 8}

Dahlan : Asyik..., aku bisa!

Maryati : Tahan, Lan, aku mau naik....

Dahlan : Ja....

(SD, Khrisna, 2012: 115)

Percakapan di atas pada saat Dahlan senang dan gembira ia bisa membawa sepeda, melihat Dahlan yang sudah bisa bawah sepada Maryati mau naik dibelakangnya Dahlan. Berdasarkan analisis percakapan tersebut Dahlan tidak melanjutkan bicaranya karena Maryati sudah naik di atas sepeda.

Maksud Dahlan jangan dulu naik karena belum maksimal bawah sepeda takut jatuh. Jadi impliktur dari percakapan di atas adalah ucapan Dahlan yang kedua.

Berdasarkan analisis tersebut maka untuk menunjang analisis, penelitian memperkuatnya dengan memaparkan ciri-ciri implikatur berikut.

1. Makna dari uacapan Dahlan yang pertama “asyik,.... Aku bisa!, uacapan Dahlan yang pertama Dahlan merasa senang dan gembira karena sudah bisa ngendarai sepeda. Ucapan Dahlan yang kedua “ja...” maksud dari ucapan tersebut Dahlan melarang Maryti untuk naik karena Dahlan belum mahir dan takut jatuh.

2. Dapat dibatalkan dari ucapan Dahlan yang pertama “ja...”, ucapan ini Dahlan membatalkan ucapan Maryti karena belum mahir bawa sepeda. 


\title{
Data 9
}

Maryati : Kapan-kapan kita coba latihan lagi, ya?

Dahlan : Takut,ah! Nanti jatuh lagi...

(SD, Khrisna, 2012: 119, 120)

Percakapan di atas Maryati mengajak Dahlan untuk berlatih bawah sepada lagi. Dahlan menjawah ia masih takut bahwa karena latih sebelumnya ia terjatuh. Dari percakapan di ata Dahlan masih trauma atau belum siapa lagi untuk berlatih lagi.

Implikatur percakapan yang timbul dalam percakapan tersebut Dahlan.

1. Dapat dibatalkan, dari ucapan Dahlan membatalkan ucapan Maryati.

2. Makna dari ucapan Dahlan "takut, ah! nanti jatuh lagi...” maknanya Dahlan takut berlatih sepeda lagi bahwa nanti lajuh lagi.

\author{
Data 10 \\ Dahlan : Ada apa Kom? \\ Komariyah : Kamu ndak sekolah? \\ Dahlan : Kenapa? \\ Komariyah : Sabar, ya...Dahlan: Sabar? \\ Komariyah : Bajumu kotor, Lan... \\ (SD, Khrisna, 2012: 124)
}

Percakapan di atas saling menimbul pertanyaan, maksud perkataan Komariyah "sabar, ya..." kalimat ini menimbulkan sebuah berita tidak baik dan memberikan ketabahan juga buat Dahlan. “bajumu kotor, Lan...” maksud dari kalimat ini Komariyah berusaha menutipi dan mengalikan perhatian Dahlan. Komariyah juga memberi tahu bahwa baju Dahlan kotor.

Berdasarkan analisis tersebut maka untuk menunjang analisis, penelitian memperkuatnya dengan memaparkan ciri-ciri implikatur berikut.

1. Makna ungkapan dari ucapan Komariyah adalah "Sabar, ya...Dahlan: Sabar”, artinya Komariyah memberikan semangat atau harus menerima apa yang terjadi.

2. Ucapan Komariyah tersebut membatalkan apa yang ditanyakan sama Dahlan, ucapan tersebut menyembunyikan.

\section{Data 11}

Dahlan : Kata Mbakyu, Ibu akan sembuh.

Mbak Atun : Kita ini manusia, Lan, ada yang ngatur.

(SD, Khrisna, 2012: 127) 
Percakapan di atas “Kita ini manusia, Lan, ada yang ngatur”, menasihatin Dahlan bahwa manusia akanmati atau meningal dan hanya Tuhan yang mengatur semua manusia akan mati atau maninggal. Jadi dari percakapan di atas yang menimbul implikatur adalah ucapan Mbak Atun.

Berdasarkan analisis tersebut maka untuk menunjang analisis, penelitian memperkuatnya dengan memaparkan ciri-ciri implikatur berikut.

1. Tak terbatas, dari ucapan Mbak Atun tidak terikat secara harfiah.

2. Dapat dibatalkan, maksud dari ucapan Mbak Atun membatalka atau menutupi dari ucapan Dahlan.

\section{Data 12}

Arif : Mana Kadir?

Imran : Males katanya.

(SD, Khrisna, 2012:173)

Percakapan di atas Imran tidak menjawab pertanyaan Arif dengan jawaban yang seharusnya. Maksud dari ucapan Imran bahwa Kadir tidak bisa ikut. Implikatur yang timbul dari percakapan di atas adalah ucapan Imran.

Berdasarkan analisis tersebut maka untuk menunjang analisis, penelitian memperkuatnya dengan memaparkan ciri-ciri implikatur berikut.

1. Ucapan Imran tak terbatas, jadi ucapan tersebut tidak terikat secara harfiah atau tidak jawaban yang seharusnya.

2. Makan ucapan Imran memberikan iformasi karena Kadir tidak bisa.

3. Ucapan Imran tak terbatas atau tidak terikat secara harfiah.

\section{Data 13}

Bapak : Dari mana, Le?

Dahlan : Maafkan Dahlan, pak.

(SD, Khrisna, 2012: 182)

Percakapan di atas Dahlan meminta maaf pada Bapaknya. Sebenanya Bapak disini tidak menyuruh Dahlan untuk minta maaf, bapak hanya menanyakan dari mana, karena Dahlan pernah melakukan kesalahan sama Bapaknya maka Dahlan melakukan minta maafnya, jadi percakapan tersebut Dahlan tidak menjawab pertayaan bapak yang seharusnya. Dari percakapan di atas yang menimbulkan implikatur adalah ucapan Dahlan. 
Berdasarkan analisis tersebut maka untuk menunjang analisis, penelitian memperkuatnya dengan memaparkan ciri-ciri implikatur berikut.

1. Tak terbatas, dari ucapan Dahlan tidak terikat sacara harfiah, apa yang ditanyakan sama Bapaknya Dahlan tidak menjawab dengan seharusnya.

2. Dari ucapan Dahlan, Dahlan membatalkan atau menutupi karena Dahlan merasa berasala dengan Bapaknya.

\title{
Data 14
}

Imran : Mau ke mana?

Dirham : Maaf, dia bukan temanku.

(SD, Khrisna, 2012: 208)

Percakapan di atas, Dirham tidak menjawab pertanyaan Imran yang seharusnya, ucapan Imran itu menanyakan pada Dirham yang berjalan keluar, sedangkan ucapan Dirham memintamaaf. “Dia bukan temanku” maksud dari kalimat ini Dirham tidak senang pada satu temannya, seakan-akan Dirham tidak mengenalnya. Implikatur dari percakapan di atas adalah ucapan Dirham.

Berdasarkan analisis tersebut maka untuk menunjang analisis, penelitian memperkuatnya dengan memaparkan ciri-ciri implikatur berikut.

1. Dari ucapan Dirham tak terbatas maksudnya tidak terikat secara harfiah atau tidak sesui dengan pertanyaan Imran.

2. Ucapan Dirham tidak terbawa dari makna ucapan Imran.

\author{
Data 15 \\ Zainal : Kenapa, Lan? \\ Dahlan : Bagianku dibungkus aja, ya? \\ Zainal : Makan disini saja. \\ Dahlan : Kasihan Zain... \\ (SD, Khrisna, 2012: 209)
}

Terjadi percakapan di atas saat pesta kupatan, ucapan Dahlan yang pertama tidak menjawab apa yang seharusnya, ucapan Zainal yang pertama menanyakan sedangkan ucapan Dahlan yang pertama menyuruhkan nasinya di bungkus aja. Ucapan Zainal yang kedua menyuruh makan di tempat situ, ucapan ucapan Dahlan yang kedua itu sebuah penolakan halus, “Kasian Zain...” maksudnya Dahlan merasa kasian sama adiknya Zain di rumah karena belum makan. 
Berdasarkan analisis tersebut maka untuk menunjang analisis, penelitian memperkuatnya dengan memaparkan ciri-ciri implikatur berikut.

1. Makna ucapan Dahlan yang dua Dahlan menimbulkan kesedihan karena Dahlan kasian sama Zain karena belum makan.

2. Ucapan Dahlan tak terikat secara harfiah atau tidak mejawab dengan seharusnya.

3. Dari ucapan Dahlan tersebut Dahlan membatalkan makan di tempat situ, karena Dahlan mengingat Zain adiknya di rumah belum makan.

\section{Data 16}

Kadir : Ibuku ndak akan pulang....

Dahlan : jangan putus asa.

(SD, Khrisna, 2012: 313)

Percakapan di atas Kadir merasa terpukul kerana Ibunya tidak akan pulang, sedangkan ucapan Dahlan member semangat apa yang dirasakan sama Kadir.

Berdasarkan analisis tersebut maka untuk menunjang analisis, penelitian memperkuatnya dengan memaparkan ciri-ciri implikatur berikut.

1. Makna ungkapan Dahlan tersebut memberi semangat karena Kadir takut Ibunya tidak akan pulang lagi. Dari ucapan Kadir “Ibuku ndak akan pulang...”, Kadir sangat sedih lihat dari ucapan tersebut menimbulkan kesedihan karena ada tanda titik.

2. Ucapan Dahlan membatalkan ucapan Kadir supaya Kadir tetap semangat.

\section{Data 17}

Aisha : Lagi sibuk banget ya, Lan?

Dahlan : Eh, ndak kok.

Aisha : kamu lewat rumahku, kan?, Bisa antar aku sampai rumah?

Dahlan : Emmm....

(SD, Khrisna, 2012: 321)

Percakapan di atas Dahlan menjawab pertanyaan Aisha dengan "Emmm..." maksud dari kalimat ini adalah diartikan sebagai “iya”, Dahlan tidak bisa jawab banyak karena gugup dihapan Aisha.

Berdasarkan analisis tersebut maka untuk menunjang analisis, penelitian memperkuatnya dengan memaparkan ciri-ciri implikatur berikut. 
1. Dari ucapan Dahlan yang pertama Dahlan membatalkan apa yang ditanya sama Aisha.

2. Makna ungkapan “eh”, kata ini mengandung makna Dahlna menutupin bahwa ia sedang sibuk dan ucapan Dahlan tersebut sambil tersenyum. “emmm....”, makna dari ucapan Dahlan ini, Dahlan mengiyakan apa yang ditanya oleh Aisha.

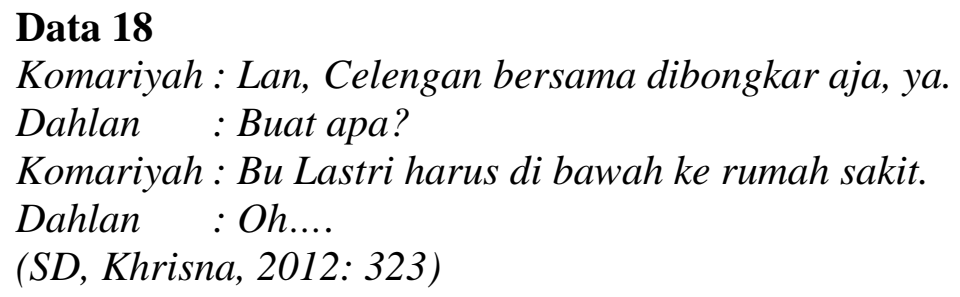

Percakapan di atas ucapan Komariyah yang pertama mengajak Dahlan untuk membongkar celengan “dibongkar" maksudnya dibuka, ucapan Dahlan yang pertama memiliki makna uang yang ada di dalam celengan tersebut buat apa, sedangkan ucapan Komariyah yang kedua menjawab dari pertanyaan Dahlan yang pertama tidak menjawab apa yang seharusnya, “Bu Lastri harus dibawah ke rumah sakit” makna dari kalimat ini ucapan Komariyah yang kedua memberi informasih bahwa Bu Lastri sakit harus bawa ke rumah sakit dan membutuhkan uang untuk berobat. ucapan Dahlan yang kedua merasa keberatan celengan itu dibuka, “oh....” Maksudnya ucapan Dahlan yang kedua sungkan kalau mengakatan tidak. Implikatur yang terdapat dalam peracakapan di atas ucapan Dahlan yang pertama dan ucapan Dahlan yang kedua.

Berdasarkan analisis tersebut maka untuk menunjang analisis, penelitian memperkuatnya dengan memaparkan ciri-ciri implikatur berikut.

1. Makna ungkapan dari ucapan Komariyah yang pertama "Lan, Celengan bersama dibongkar aja, ya”, celengan dibuka saja “dibongkar” kata ini maksudnya dibukakan. Ucapan Komariyah yang kedua "Bu Lastri harus bawa ke rumah saki”, ucapan ini bahwa Ibu Lastri sedang sakit parah harus bawa ke rumah sakit dan memberikan informasi pada Dahlan karena Ibu Lastri lagi sakit parah. Ucapan Dahlan yang kedua tidak bisa ngomong lagi karena uang yang mereka nabung sangat dibutuhkan dan ucapan tersebut menyetujui, kata “oh....” Makna yang tersimpan. 
2. Ucapan Komariyah yang kedua tak terbatas Karen tudak terikan sacara harfiah.

\section{Data 19}

Dahlan : Sepedaku rusak, ndak mungkin dipakai.

Aisha : Emmm.... Kita jalan kaki aja.

(SD, Khrisna, 2012: 328)

Percakapan di atas Aisha menjawab ucapan Dahlan dengan “emmm... kita jalan kaki aja” makna dari kami tersebut Aisha memahami bahwa sepeda tersebut sedang rusak dan Aisha menyuruh Dahlan untuk jalan kaki aja. Jadi implikatur yang timbul dalam percakapa di atas adalah “emmm...”. Implikatur yang terdapat dalam percakapan di atas ucapan Aisha.

Berdasarkan analisis tersebut maka untuk menunjang analisis, penelitian memperkuatnya dengan memaparkan ciri-ciri implikatur berikut.

1. Makna dari ucapan Aisha, ia memahami bahwa sedepa tersebut sedang rusak tidak bisa bawa.

\section{Data 20}

Arif : : Aku harap kalian semua datang pada saat pernikahan kami.

Imran : Kami?

Kadir : Oh....

(SD, Khrisna, 2012: 344)

Percakapan di atas Arif berharap teman-temannya datang pada saat pernikahannya nanti, Imran menjawab ucapan Arif dengan pertanyaan “kami?”. Makna dari pertanyaan Imran seakan-akan yang menikah itu banyak. Dari ucapan Arif di atas menunjukan kata "kami”, maksud dari kalimat tersebut adalah Arif dengan pasangannya yang menikah. Dari ucapan Kadir “oh...' Kadir bergembira sambil bertepuk tangan, karena Kadir senang dan bahagia mendengar temannya yang mau menikah dan mungkin Kadir akan datang kepada pernikahan temannya. Implikatur yang dapat dalam percakapan di atas ada dua ucapan Imran dan Kadir.

Berdasarkan analisis tersebut maka untuk menunjang analisis, penelitian memperkuatnya dengan memaparkan ciri-ciri implikatur berikut.

1. Makna dari ucapan Imran seakan yang menikah itu banyak orang karena dari ucapan arfri menimbulkan kata "kami”, makan dari itu ucapan Imran tersebut menimbulkan tanda Tanya. 
2. Dari ucapan kadir tidak terikat secara harfiah.

\section{Data 21}

Dahlan : Aku ndak bisa kuliah, Rif. Duit dari mana?

Arif : Gusti Allah ora tahu turu, Lan!

Dahlan : Tapi....

(SD, Khrisna, 2012: 352)

Percakapan di atas ucapan Dahlan yang pertama, Dahlan member informasi bahwa Dahlan tidak bisa kuliah karena tidak punya uang. Dari ucapan Arif “Gusti Allah ora tahu turu, Lan!” makna dari ucapan Arif tersebut berdo'a kepada Allah supaya kita dikasi jalan sama Allah. Ucapan Dahlan yang kedua, Dahlan menggunakan kata “tapi....” Karena tidak tahu apa yang diomongin lagi. Jadi implikatur yang terdapat dalam percakapan di atas adalah ucapan Dahlan yang kedua.

Berdasarkan analisis tersebut maka untuk menunjang analisis, penelitian memperkuatnya dengan memaparkan ciri-ciri implikatur berikut.

1. Makna ungkapan maksud atau makna dari ucapan Afri tersebut, berdo'alah kepada Allah bahwa apa yang kita minta akan dikabulkan yang penting berusaha. Dan makna dari ucapan Dahlan yang kedua tidak tahu apa yang apa yang harus diomongin lagi.

2. Dari ucapan Afri tidak terikat secara harfiah atau tidak jawab dengan seharusnya.

\section{Data 22}

Arif : : Aku ndak percaya Sampean ndak akan mbalas surat itu.

Dahlan : Emmm.... Banyak hal yang mau kutanya ke Aisha.

(SD, Khrisna, 2012: 353)

Dari percakapan di atas Dahlan hanya bilang "emmm.... Banyak hal yang mau kutanyakan” Dahlan ragu-ragu apa yang dikatakan sama Arif, sedang ucapan Arif tersebut seolah-olah Arif menantang Dahlan untuk balas surat itu. Jadi implikatur yang dapat dalam percakapan di atas adalah ucapan Dahlan.

\section{Data 23}

Bapak : Ada apa?

Dahlan : Pak....

Bapak : Bilang saja!

(SD, Khrisna, 2012: 354) 
Percakapan di atas terjadi Bapak dan Dahlan lagi duduk santai di rumah, Bapak bertanya sama Dahlan karena Bapak melihat Dahlan sedang bingung. Dahlan tidak berani ngomong apa yang mau di omongin, Dahlan takut nanti Bapaknya marah. Jadi implikatur yang terdapat dari percakapan di atas ucapan Dahlan.

Berdasarkan analisis tersebut maka untuk menunjang analisis, penelitian memperkuatnya dengan memaparkan ciri-ciri implikatur berikut.

1. Makna dari kata "pak....", adalah ucapan tersebut Dahlan sungkan apa yang ditanyakan sama Bapaknya.

2. Ucapan Dahlan membatalkan apa yang ditanyakan sama Bapaknya.

\section{PENUTUP}

Penelitian ini adalah "Implikatur Dalam Novel Sepada Dahlan karya Khrisna Pabichara”, hasil dari penelitian dalam novel Sepatu Dahlan tersebut terdapat 23 implikatur percakapan.

Implikatur percakapan adalah implikasi pragmatik yang tersirat di dalam suatu percakapan. di dalam komunikasi, tuturan selalu menyajikan suatu fungsin pragmatik dan di dalam tuturan percakapan itulah terimplikasi suatu maksud atau tersirat. Implikatur yang diperoleh dalam penelitian ini adalah implikatur konversional.

\section{DAFTAR RUJUKAN}

Hernita. 2014. Implikatur Percakapan pada Novel 99 Cahaya di Langit Eropa Karya anum Salabiela Rais dan Rangga Almahendra serta Implikatur Terahadap Pembelajaran Bahasa dan Satra Indonesia. Jakarta, Universitas Islam Negeri Syafir Hidayatullah.

Hindun. 2012. Pragmatik Untuk Perguruan Tinggi. Jakarta, Nufa Citra.

Kosasih. 2011. E. Dasar-dasar keterampilan Bersastra. Bandung, Y rama Widya.

Kridalaksana, Harimurti dan Wijana. 1994. Kamus Linguistik. Jakarta: PT. Gramedia

Leech, Geoffrey. 1991. Principle of pragmatics. London: Longman,

Levinsio dan Rahardi. 2003. Presumptive Meaning: The Theory of generalized Conversational Implicature. Cambridge. Mass: MTT press.

Santori, Komariah. 2014. Metodologi Penelitian Kualitatif. cv. Bandung, Alfabeta.

Santoso, Wijaya Heru dan Wahyuningtyas, dan Sri. 2010. Pengantar Apresiasi Prosa. 
Sugiyono. 2013. Metode Penalitian Pendidikan (pendekatan kuantitatif, kualitatif, dan $R \& D)$. cv Bandung, Alfabeta.

Teew, A. 1988 Sastra dan Ilmu sastra, Pengantar Teori. Jakarta. Pustaka Jaya.

Wellek, Rene dan Austin Warren. 1993 (penerjemah: Melani Budiatan). Teori Kesusastraan. Jakarta, Gramedia Pustaka Utama.

Yule, George 2006. Pragmatics Oxford University Press.Yogyakarta, Pustaka Pelajar. 